North American Journal of Fisheries Management, v. 10, iss. 2, May 1990, pp. 209 223.

http://afs.allenpress.com/perlserv/?request=get-archive

http://afs.allenpress.com/archive/1548-8675/10/2/pdf/i1548-8675-10-2-209.pdf

Online ISSN: 1548-8675

Print ISSN: 0275-5947

DOI: 10.1577/1548-8675(1990)010<0209:MSTESF>2.3.CO;2

(C) American Fisheries Society 


\title{
Manipulating Shad to Enhance Sport Fisheries in North America: An Assessment
}

\author{
DenNis R. DeVries' and Roy A. Stein \\ The Ohio Cooperative Fish and Wildlife Research Unit ${ }^{2}$ and \\ Department of Zoology. The Ohio State University \\ Columbus, Ohio 43210, USA
}

\begin{abstract}
Manipulating forage fish populations to enhance sport fisheries is a common management practice. Here we review the literature dealing with manipulations of gizzard shad Dorosoma cepedianum and threadfin shad $D$. petenense to assess whether or not this practice has been successful. Shad introduction has tended to enhance predators, such as white crappie Pomoxis annularis, black crappie $P$. nigromaculatus, and largemouth bass Micropterus salmoides, and negatively affect presumed competitors, such as bluegill Lepomis macrochirus. However, responses have not been consistent within a species: some studies document negative responses of predators or positive responses of competitors to shad introduction. Depending on the study, target species have experienced negative, neutral, and positive effects due to shad removal, making generalizations impossible. Inadequate statistical analyses coupled with problems with study design further complicated interpretation of these studies. In addition, because resident predators feeding on introduced prey constitute only a portion of the complex of interactions that occur in a lake, factors such as multiple trophic levels, ontogenetic shifts in diet and habitat, and spatial heterogeneity must be considered when attempts are made to predict the outcome of forage-fish manipulations.
\end{abstract}

Approaches used by fisheries biologists to manage aquatic systems for sport-fish production have evolved during the past 40-50 years. Initially, management practices emphasized single-species approaches, such as stocking game fish, limiting catch, and instituting length limits and seasons. Since the 1950 s, however, managers have also manipulated forage fishes to enhance predator growth. These practices have become widespread (see reviews in Ney 1981; Noble 1981; Wydoski and Bennett 1981; Noble 1986), contributing to the variety of tools available for managing lakes and rescrvoirs. Though these manipulations sometimes positively influence target species. negative results also have been documented, suggesting the need for an assessment of the overall benefits of this practice. Herein we review the results of forage-fish manipulations to determine whether such manipulations tend to improve a fishery or possibly contribute to its decline.

Given that forage-fish manipulation may produce responses in sport fishes that are specific to the prey being manipulated, we chose to limit our review to manipulations involving related forage

\footnotetext{
1 Present address: Department of Fisheries and Allied Aquacultures, Auburn University, Alabama 36849, USA.

2 The Unit is sponsored jointly by the U.S. Fish and Wildlife Service, Ohio Department of Natural Resources, The Ohio State University, and the Wildlife Management Institute.
}

fishes. A number of taxa have been manipulated, including members of Atherinidae, Catostomidae, Clupeidae, Coregonidae, Cyprinidae, and Percidae (e.g., see references in Ellis 1978; Ney 1981; Noble 1981; Wydoski and Bennett 1981; Moyle 1986; Werner 1986). However, our search revealed that shad (both gizzard shad Dorosoma cepedianum and threadfin shad $D$. petenense) were manipulated at least 10 times more often than any other group. Because we wanted to draw conclusions as to the overall effect of forage-fish manipulations across a wide range of systems, the number of published studies was an important consideration. Furthermore, both species of shad are important forage species in much of North America (Lewis and Helms 1964; Aggus 1974; Carline et al. 1986; Johnson et al. 1988). Thus, our review is limited to studies of manipulations involving shad.

\section{Methods}

We considered an introduction to be the addition of a shad to a system not containing that species. Introductions included deliberate stockings, accidental introductions (e.g., shad inadvertently introduced when another species was stocked), or additions due to unknown causes (e.g.. unauthorized persons stocking fish or fish moving downstream into a lake). Removals were any measurable reduction of a shad population, including 
deliberate removals as well as reductions due to winterkill.

All studies were evaluated against objective criteria to determine whether a paper would make a meaningful contribution to our ability to generalize from the review. Though we considered a variety of criteria, only two determined whether a study would be included. First, we required documentation of the success of an introduction or removal. Shad abundance estimates from pre- as well as posttreatment years were necessary to permit valid comparisons across years, before and after the manipulation. Without these data, changes in the target species might reflect normal year-toyear variability rather than changes resulting directly from the manipulation. For shad introductions, this criterion was loosely applied; if shad were sampled from the lake after introduction, we considered the introduction successful. We included studies with either explicit sampling for shad or the presence of shad in the diets of predator fishes. Similarly, removal success was documented by sampling after a removal to quantify a reduction in abundance or to demonstrate complete absence of shad. Our second criterion was that the variable of interest (e.g., length at age, harvest) had to be quantified both before and after the manipulation. Posttreatment data had to be compared explicitly to pretreatment data collected in a similar way for changes to be attributed to the manipulation. For our purposes, back-calculated growth rates were acceptable for comparisons. Studies meeting both criteria are discussed below.

\section{Results}

Shad manipulations have occurred in a broad geographic band through the midwestern USA, from Oklahoma and Kansas east to Virginia (Figure 1). Fewer manipulations occurred in the southeastern and southwestern portions of the country, and none occurred in the upper Midwest, the $\mathrm{Pa}$ cific Northwest, or the northeastern USA. Almost no manipulations occurred within the native range of the threadfin shad (Figure 1). Manipulations outside the native range of threadfin shad should seemingly only have been introductions; however, $20 \%$ of manipulations of threadfin shad outside their range were removals, including studies of reduction due to winterkill or predator addition. Only one threadfin shad manipulation involved a deliberate removal. In contrast, about $80 \%$ of the gizzard shad manipulations involved removal rather than addition (Figure 1). No reports were found on gizzard shad introduction into lakes out- side their native range. Thus, threadfin shad were stocked more commonly as a forage fish, whereas gizzard shad were removed more commonly (Figure 1). This observation reflects two facts: (1) threadfin shad has a much smaller native range than gizzard shad, and (2) threadfin shad is viewed as a more desirable forage species than gizzard shad due to its smaller maximum size.

Of 60 papers dealing with shad manipulations, 43 dealt with shad introductions and 17 with shad removals (Tables 1, 2). Forty-four percent of the introductions and $33 \%$ of the removals met both of our criteria. Target species examined in studies that met both criteria were almost exclusively sport fishes. Most often studied were largemouth bass Micropterus salmoides (in 16 introductions and 6 removals), white crappie Pomoxis annularis and black crappie $P$. nigromaculatus ( 14 introductions and 6 removals), and bluegill Lepomis macrochirus (12 introductions and 5 removals). Species studied less often included walleye Stizostedion vitreum (three introductions), smallmouth bass Micropterus dolomieui (three introductions), green sunfish Lepomis cyanellus (one introduction), spotted bass Micropterus punctulatus (one introduction), and redear sunfish Lepomis microlophus (one removal). In addition, changes in the zooplankton community due to three shad introductions were examined.

The variable used most often to determine shad effects, in both introductions and removals, was some estimate of growth, such as length at age (13 introductions and 3 removals). Catch, catch per unit effor, and total harvest (nine introductions and one removal), condition factor and relative weight (six introductions and one removal), and diet (four introductions) also were evaluated.

\section{Responses to Manipulations}

Because largemouth bass, crappies (black and white), and bluegill were clearly the most frequent target species, we chose to evaluate the effects of shad manipulations on these species. The potential influence of shad follows from the functional roles of the four target species in aquatic systems. We expected growth of piscivores, such as largemouth bass and crappies, to increase when shad were added. Bluegill, as a potential competitor with shad, should have grown more slowly after shad were added. In turn, removing shad should reduce piscivore growth and increase that of competitors. We categorized the overall outcome of each manipulation as positive, neutral, negative, or mixed. For example, when all monitored variables asso- 


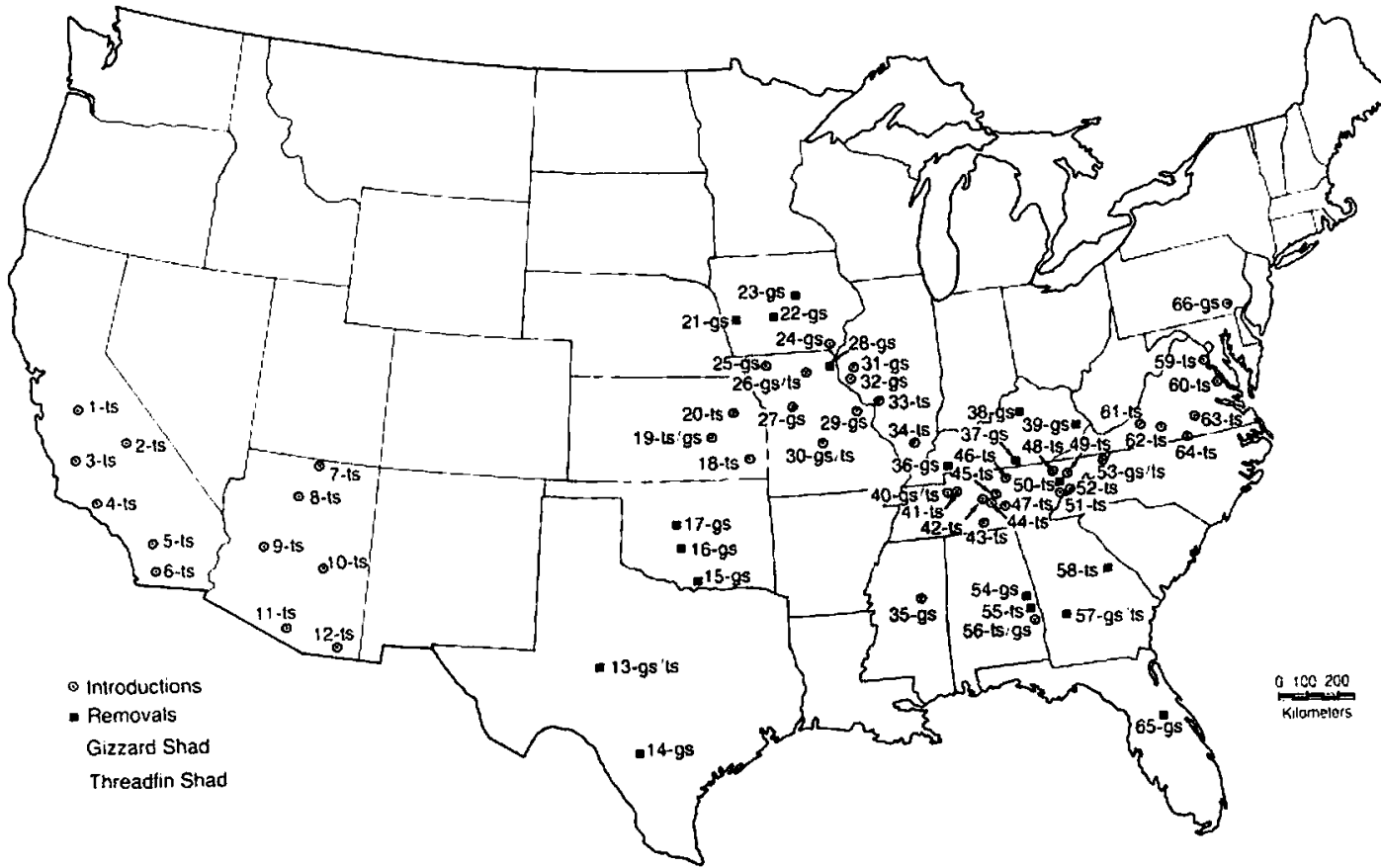

FIGURE 1.-Map representing the distribution of U.S. water bodies where gizzard shad (gs) and threadfin shad (ts) were introduced or removed. Superimposed on the map is the natural range of these two species (from Trautman 1981). Lake numbers correspond to numbers used in Tabies 1 and 2 and in Figures 2 and 3.

ciated with a target species showed positive responses to shad manipulation, the overall result for the target species in that study was positive. If some variables indicated improvement whereas others did not (i.e., they were either neutral or negative), then results were mixed. Because most studies (i.e., $80 \%$ of introductions and $71 \%$ of removals meeting both of our criteria) did not include statistical analysis or estimates of variation around measured variables, we could not objectively determine whether or not the response of a target species was significant. Thus, we had to rely on author-generated conclusions from each manipulation.

As expected, the response of crappies to shad addition was skewed toward positive effects (seven studies), but two studies documented negative effects, two documented neutral effects, and three revealed mixed responses (Figure 2). Similarly, the response of largemouth bass to shad introduction was skewed toward positive effects (seven studies), but nine studies demonstrated negative, neutral, or mixed responses (Figure 2). Bluegill, as a potential competitor with shad, had fewer positive responses to shad addition than did crappies or largemouth bass (one study), but only three studies revealed negative effects (Figure 2). Shad removal led to highly variable results for all four species (Figure 3). All species experienced positive, neutral, and negative effects from shad removal, with each category containing one or two responses, making generalizations impossible.

\section{Discussion}

We were not able to generalize about how shad influence sport fishes. Although bluegill appeared to be more negatively affected by shad than crappies, the response of largemouth bass being intermediate between the two, we cannot draw definite conclusions because the entire range of results occurred for each target species. We will address two possible reasons for this lack of generalization, after which we will discuss several ideas that can improve our understanding of studies of species manipulations. Finally, we will present an alternative approach for studies designed to evaluate the overall impact of species manipulations.

\section{Why No Generalizations?}

Changes in response variables due to shad manipulation were difficult to interpret because most investigators did not analyze their data statisti- 
TABLE 1.-A summary of studies of shad introductions. Study numbers refer to lake locations in Figure 1. A plus sign $(+)$ following a study number indicates studies meeting criteria 1 and $2 .^{\text {a }}$ Results from studies that met criteria 1 and 2 were used to generate our primary conclusions about the effects of shad introduction. $Y=$ criterion met; $\mathrm{N}=$ criterion not met; $\mathrm{NA}=$ introduction was unsuccessful.

\begin{tabular}{|c|c|c|c|c|c|c|}
\hline \multirow[b]{2}{*}{ State and waters } & \multirow{2}{*}{$\begin{array}{c}\text { Study } \\
\text { number }\end{array}$} & \multicolumn{4}{|c|}{ Criterion $^{a}$} & \multirow[b]{2}{*}{ Reference } \\
\hline & & 1 & 2 & 3 & 4 & \\
\hline \multicolumn{7}{|l|}{ California } \\
\hline Millerton Reservoir & 1 & $\mathbf{N}$ & $\mathbf{Y}$ & $\mathbf{N}$ & $\mathrm{N}$ & Miller (1971); VonGeldern and Mitchell (1975) \\
\hline Pine Flat Reservoir & 2 & $\mathbf{N}$ & $\mathbf{Y}$ & $\mathbf{N}$ & $\mathbf{N}$ & Miller (1971) \\
\hline Lake Naciemiento & 3 & $\mathbf{N}$ & $\mathbf{N}$ & $\mathbf{Y}$ & $\mathbf{N}$ & VonGeldern (1971) \\
\hline Isabella Reservoir & $4+$ & $\mathbf{Y}$ & $\mathbf{Y}$ & $\mathbf{Y}$ & $\mathbf{N}$ & Bartholomew (1966) \\
\hline Sutherland Reservoir & 5 & $\mathbf{N}$ & $\mathbf{Y}$ & $\mathbf{Y}$ & $\mathbf{N}$ & LaFaunce et al. (1964) \\
\hline El Capitan Reservoir & 6 & $\mathbf{N}$ & $\mathbf{Y}$ & $\mathbf{N}$ & $\mathbf{Y}$ & Fast et al. (1982) \\
\hline \multicolumn{7}{|l|}{ Arizona } \\
\hline Lake Powell (Arizona and Utah) & $7 \mathbf{a}+$ & $\mathbf{Y}$ & $\mathbf{Y}$ & $\mathbf{N}$ & $\mathbf{Y}$ & Hepworth and Gloss (1976) \\
\hline & $7 b+$ & $\mathbf{Y}$ & $\mathbf{Y}$ & $\mathbf{N}$ & $\mathbf{N}$ & $\begin{array}{l}\text { Hepworth and Pettengill (1980); May and Thompson } \\
\text { (1974); May et al. (1975) }\end{array}$ \\
\hline Lake Havasu & $8+$ & $\mathbf{Y}$ & $\mathbf{Y}$ & $\mathbf{Y}$ & $\mathbf{N}$ & Kimsey et al. (1957) \\
\hline Alamo Lake & $9+$ & $\mathbf{Y}$ & $\mathbf{Y}$ & $\mathbf{N}$ & $\mathbf{N}$ & Ziebell et al. (1986) \\
\hline Roosevelt Lake & 10 & $\mathbf{Y}$ & $\mathbf{N}$ & $\mathbf{N}$ & $\mathbf{N}$ & Beers (1965); Beers and McConnell (1966) \\
\hline Pena Blanca Lake & 11 & $\mathbf{N}$ & $\mathbf{N}$ & $\mathbf{N}$ & $\mathbf{N}$ & McConnell and Gerdes (1964) \\
\hline Patagonia Lake & $12+$ & $\mathrm{Y}$ & $\mathbf{Y}$ & $\mathbf{N}$ & $\mathbf{N}$ & Ziebell et al. (1986) \\
\hline \multicolumn{7}{|l|}{ Kansas } \\
\hline \multirow{3}{*}{$\begin{array}{l}\text { Geary State Fishing Lake } \\
\text { Lyon State Fishing Lake } \\
\text { (=Lake Reading) }\end{array}$} & $18+$ & $\mathbf{Y}$ & $\mathrm{Y}$ & $\mathrm{Y}$ & $\mathbf{N}$ & Mosher (1984a) \\
\hline & $19 a+$ & $\mathrm{Y}$ & $\mathbf{Y}$ & $\mathbf{Y}$ & $\mathbf{N}$ & Mosher (1984a) \\
\hline & $19 b+$ & c & $\mathbf{Y}$ & c & $N$ & Prophet $(1982,1985,1988)$ \\
\hline Osage State Fishing Lake & $20+$ & $\mathbf{Y}$ & $\mathbf{Y}$ & $\mathbf{Y}$ & $\mathbf{N}$ & Mosher (1983, 1984a. 1984b) \\
\hline \multicolumn{7}{|l|}{ lowa } \\
\hline Lake Geode & $24+$ & $\mathrm{Y}$ & $\mathbf{Y}$ & $\mathbf{N}$ & $\mathbf{N}$ & Kline (1983) \\
\hline \multicolumn{7}{|l|}{ Missouri } \\
\hline Worth County Community Lake & 25 & $\mathbf{N}$ & $\mathbf{Y}$ & $\mathbf{Y}$ & $\mathbf{N}$ & Rasmussen and Michaelson (1974); Eder (1983) \\
\hline Hunnewell Lake & 26 & $\mathbf{N}$ & $\mathrm{Y}$ & $\mathbf{Y}$ & $\mathbf{N}$ & Brummett (1983) \\
\hline Jamesport Community Lake & 27 & $\mathbf{N}$ & $\mathbf{Y}$ & $\mathbf{Y}$ & $\mathrm{N}$ & Rasmussen and Michaelson (1974); Eder (1983) \\
\hline Pony Express Lake & 29 & $N$ & 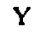 & $\mathrm{Y}$ & $\mathbf{N}$ & Eder $(1983)$ \\
\hline Little Dixie Lake (TS) & $30 a+$ & $\mathbf{Y}$ & $\mathbf{Y}$ & $\mathbf{Y}$ & $\mathbf{N}$ & Norwat (1978) \\
\hline Little Dixic Lake (GS)d & $30 \mathrm{~b}+$ & $\mathbf{Y}$ & $\mathbf{Y}$ & $\mathbf{Y}$ & $\mathbf{N}$ & Anderson (1983) \\
\hline \multicolumn{7}{|l|}{ Illinois } \\
\hline Argyle Lake & $31+$ & $\mathrm{Y}$ & $Y$ & $\mathbf{N}$ & $\mathbf{N}$ & Russell (1983) \\
\hline Spring Lake & $32+$ & $\mathbf{Y}$ & $\mathbf{Y}$ & $\mathbf{N}$ & $\mathbf{N}$ & Jahn (1983) \\
\hline Little Grassy Lake & 33 & $Y$ & $\mathbf{N}$ & $\mathbf{Y}$ & $\mathbf{N}$ & Heidinger and Imboden (1974) \\
\hline Lake of Egypt & $34+$ & $\mathbf{Y}$ & $\mathbf{Y}$ & $\mathbf{Y}$ & $\mathbf{N}$ & Heidinger (1977) \\
\hline \multicolumn{7}{|l|}{ Mississippi } \\
\hline Lake Paho & $35+$ & $\mathbf{Y}$ & $\mathbf{Y}$ & $\mathrm{Y}$ & $\mathbf{N}$ & Neuswanger (1983) \\
\hline \multicolumn{7}{|l|}{ Tennessee } \\
\hline Great Falls Lake (GS) ${ }^{d}$ & 40 & $\mathbf{Y}$ & $N$ & $\mathbf{N}$ & $\mathbf{N}$ & Fetterolf (1957) \\
\hline Great Falls Lake (TS) & 40 & $Y$ & $\mathrm{~N}$ & $Y$ & $N$ & Fetterolf (1957) \\
\hline Cheatham Lake & 41 & $Y$ & $\mathbf{N}$ & $\mathrm{N}$ & $N$ & Fetterolf (1957) \\
\hline Crossville City Reservoir & 42 & $\mathbf{N}$ & $\mathbf{N}$ & $\mathbf{Y}$ & $\mathbf{N}$ & Fetterolf (1957) \\
\hline Lake Woods & 43 & $\mathbf{Y}$ & $\mathbf{N}$ & $\mathbf{Y}$ & $\mathbf{N}$ & Fetterolf (1957) \\
\hline McMinnville City Lake & 44 & $\mathbf{N}$ & $\mathrm{N}$ & $\mathbf{Y}$ & $\mathbf{N}$ & Fetterolf (1957) \\
\hline Center Hill Reservoir & 45 & $Y$ & $N$ & $N$ & $N$ & Fetterolf (1957) \\
\hline \multirow[t]{3}{*}{ Dale Hollow Reservoir } & 46 & $\mathbf{Y}$ & $N$ & $\mathrm{Y}$ & $\mathbf{N}$ & Fetterolf (1957) \\
\hline & 46 & $\mathbf{Y}$ & $N$ & $\mathbf{N}$ & $\mathbf{Y}$ & Myhr (1971) \\
\hline & $46+$ & $\mathrm{Y}$ & $\mathrm{Y}$ & $\mathbf{Y}$ & $\mathbf{Y}$ & Range (1973) \\
\hline Old Hickory Reservoir & 47 & $\mathrm{Y}$ & $\mathbf{N}$ & $\mathbf{N}$ & $\mathbf{N}$ & Fetterolf (1957) \\
\hline Norris Lake & 48 & $\mathrm{Y}$ & $\mathbf{N}$ & $\mathbf{Y}$ & $\mathbf{N}$ & Fetterolf (1957) \\
\hline Cherokee Lake & 49 & $\mathbf{Y}$ & $\mathbf{N}$ & $\mathbf{N}$ & $\mathbf{N}$ & Fetterolf (1957) \\
\hline Douglas Lake & 51 & $\mathbf{Y}$ & $\mathbf{N}$ & $\mathbf{Y}$ & $\mathbf{N}$ & Fetterolf (1957) \\
\hline South Holston Reservoir & 52 & $\mathbf{N}$ & $\mathbf{N}$ & $Y$ & $\mathbf{N}$ & Fetterolf (1957) \\
\hline Watauga Reservoir (GS) & 53 & $\mathbf{Y}$ & $\mathbf{N}$ & $\mathbf{N}$ & $\mathbf{N}$ & Fetterolf (1957) \\
\hline Watauga Reservoir (TS) & 53 & $\mathbf{N}$ & $\mathrm{N}$ & $\mathrm{Y}$ & $\mathbf{N}$ & Fetterolf (1957) \\
\hline \multicolumn{7}{|l|}{ Alabama } \\
\hline Aubum University ponds & 56 & $N$ & $\mathbf{Y}$ & $\mathbf{Y}$ & $N$ & Davies et al. (1979) \\
\hline & $56+$ & $\mathbf{Y}$ & $\mathbf{Y}$ & $\mathbf{Y}$ & $\mathbf{Y}$ & Kirk (1984); Kirk and Davies (1987) \\
\hline Georgia & & & & & & \\
\hline Blackshear Lake & 57 & $\mathbf{Y}$ & $N$ & $\mathbf{Y}$ & $\mathbf{N}$ & Wyatt and Zeller (1965); Zeller and Wyatt (1967) \\
\hline
\end{tabular}


TABLE 1.-Continued.

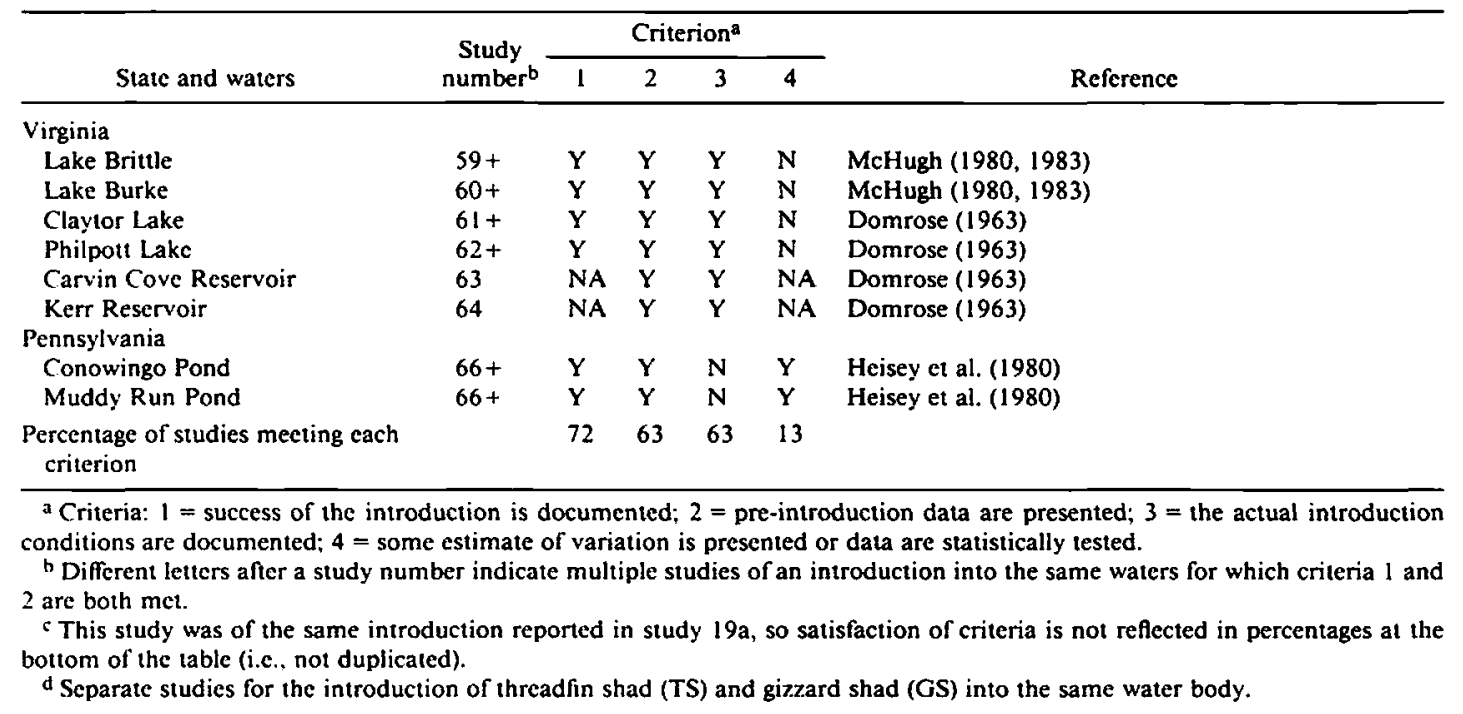

cally. We were unable to determine whether "trends" in pre- versus postmanipulation data represented real differences or just random variation with no differences in mean values. Thus, we had to rely on the author's conclusions for determining the overall effect of shad on target species, which introduced investigator bias as a factor that might be responsible, in part, for the skew in our results. If an investigator expects shad to enhance predators (or negatively influence competitors), then positive (or negative) results may be accepted, even though response variables do not differ statistically between pre- and postmanipulation sampling periods. It is possible that, among the range of responses obtained, some studics yielded significant differences, whereas others had only nonsignificant "trends." If the significant differences were all positive or negative for a given species, and if the remainder were neutral "trends," then results might be generalizable. Valid conclusions only can be reached by statistically comparing data from before and after the treatment.

In addition, most studies focused on the effects of shad on adult sport fish, the life stage of interest to anglers. Fish at other life stages can be affected by these manipulations, and their responses will influence the ultimate outcome of the manipulation. Young-of-year fishes feed on zooplankton (e.g., Cramer and Marzolf 1970; Barger and Kilambi 1980; Keast 1980, 1985a; Van Den Avyle and Wilson 1980; Lemly and Dimmick 1982; Mathias and $\mathrm{Li}$ 1982) and may compete with zoo- planktivorous shad. Several studies included in our review (Prophet 1982, 1985, 1988; Zicbell et al. 1986; see also DeVries 1989) documented how shad can severely depress zooplankton abundance. This effect on zooplankton may reduce recruitment of such sport fishes as bluegill and crappies, whose limnetic larvae feed on zooplankton for as long as 4-6 weeks (Werner 1967,1969; Keast 1980; Beard 1982). The negative effect of reduced z.ooplankton abundance on sport-fish recruitment would not be detected for several years in studies focused on adult sport fish. Almost no studies reviewed here included data on the abundance of young-of-year sport fish (but see Kirk and Davies 1987; Kirk et al. 1986); if they had, negative effects of shad introductions may have been more evident.

\section{How Can We Improve Studies of Forage-Fish Manipulations?}

Assessment of forage-fish manipulations can be improved by careful attention to initial study design and additional data collection. Though we do not argue that the following is the formula for a perfect study, we believe these features should be considered when forage-fish manipulations are contemplated.

Describe the site. - Basic descriptive information, including nutrient levels, size structure of predator populations, etc., should be reported to permit comparison among systems. For example, availability of structure, such as macrophytes, or 
TABle 2.-A summary of studies of shad removals. Study numbers refer to lake locations in Figure 1. A plus sign $(+)$ following a study number indicates those meeting criteria 1 and $2 .^{\text {a }}$ Results from studies that met criteria 1 and 2 were used to generate our primary conclusions about the effects of shad removal. A dash in place of a study number indicates a lake not on Figure 1 . $Y=$ criterion met; $N=$ criterion not met; $N A=$ introduction was unsuccessful.

\begin{tabular}{|c|c|c|c|c|c|c|}
\hline \multirow[b]{2}{*}{ State and waters } & \multirow{2}{*}{$\begin{array}{l}\text { Study } \\
\text { number }\end{array}$} & \multicolumn{4}{|c|}{ Criteria $^{\mathrm{a}}$} & \multirow[b]{2}{*}{ Reference } \\
\hline & & 1 & 2 & 3 & 4 & \\
\hline \multicolumn{7}{|l|}{ Texas } \\
\hline Lake E.V. Spence & 13 & $\mathbf{Y}$ & $\mathrm{N}$ & $\mathbf{N}$ & $\mathrm{N}$ & Morris and Follis (1979) \\
\hline Medina Lake & $14^{*}$ & $\mathbf{Y}$ & $\mathbf{Y}$ & $Y$ & $\mathrm{Y}$ & Dietz and Jurgens (1963) \\
\hline \multicolumn{7}{|l|}{ Oklahoma } \\
\hline Lake Murtay & $15^{\circ}$ & $\mathbf{Y}$ & $\mathbf{Y}$ & $\mathbf{Y}$ & $\mathbf{N}$ & Sandoz (1956) \\
\hline Spavinaw Lake & 16 & $N$ & $N$ & $\mathbf{Y}$ & $\mathbf{N}$ & Jackson (1966) \\
\hline Lake Eucha & 17 & $\mathbf{N}$ & $\mathbf{N}$ & $\mathbf{Y}$ & $\mathbf{N}$ & Jackson (1966) \\
\hline \multicolumn{7}{|l|}{ Iowa } \\
\hline Prairie Rose Lake & 21 & $\mathbf{N}$ & $\mathbf{Y}$ & $\mathbf{Y}$ & $\mathbf{N}$ & Putnam (1983) \\
\hline Lake Ahquabi & 22 & $\mathbf{N}$ & $\mathbf{Y}$ & $\mathbf{Y}$ & $\mathbf{N}$ & Putnam (1983) \\
\hline Blackhawk Lake & 23 & $\mathbf{Y}$ & $\mathbf{N}$ & $\mathbf{Y}$ & $\mathbf{N}$ & Rose (1957) \\
\hline \multicolumn{7}{|l|}{ Missouri } \\
\hline Deer Ridge Community Lake & $28^{+}$ & $Y$ & $\mathbf{Y}$ & $\mathbf{Y}$ & $\mathbf{N}$ & Brummett (1983) \\
\hline \multicolumn{7}{|l|}{ Kentucky } \\
\hline Shanty Hollow Lake & $36^{+}$ & $\mathbf{Y}$ & $\mathbf{Y}$ & $\mathbf{Y}$ & $\mathbf{N}$ & Smith (1959) \\
\hline Carpenter's Lake & 37 & $\mathbf{Y}$ & $\mathbf{N}$ & $\mathbf{Y}$ & $\mathbf{N}$ & Smith (1959) \\
\hline Herrington Lake & 38 & $\mathbf{Y}$ & $\mathrm{N}$ & $\mathbf{Y}$ & $\mathbf{N}$ & Smith (1959) \\
\hline Dewey Lake & $39^{\circ}$ & $\mathbf{Y}$ & $\mathbf{Y}$ & $\mathbf{Y}$ & $\mathbf{N}$ & Smith (1959) \\
\hline \multicolumn{7}{|l|}{ Tennessee } \\
\hline Watts Bar Reservoir & $50 \mathrm{a}$ & $N$ & $\mathbf{Y}$ & $\mathbf{Y}$ & $\mathbf{N}$ & McGec et al. (1979) \\
\hline & $50 \mathrm{~b}$ & b & $\mathbf{Y}$ & b & $\mathbf{N}$ & McLean et al. (1985) \\
\hline \multicolumn{7}{|l|}{ Alabama } \\
\hline Chambers County Lake & 54 & $\mathbf{N}$ & $\mathbf{Y}$ & $\mathbf{Y}$ & $\mathbf{N}$ & Kirk (1984); Kirk et al. (1986) \\
\hline Lee County Lake & 55 & $\mathbf{N}$ & $\mathbf{Y}$ & $\mathbf{Y}$ & $\mathbf{N}$ & Moss and Reeves (1983) \\
\hline \multicolumn{7}{|l|}{ Georgia } \\
\hline Blackshear Lake & $57^{*}$ & $\mathbf{Y}$ & $\mathbf{Y}$ & $\mathbf{Y}$ & $\mathbf{N}$ & Wyatt and Zeller (1965); Zeller and Wyatt (1967) \\
\hline Lake Jackson & $58^{\circ}$ & $\mathrm{Y}$ & $\mathbf{Y}$ & $\mathbf{Y}$ & $\mathbf{Y}$ & Ellis (1981) \\
\hline \multicolumn{7}{|l|}{ Florida } \\
\hline Deer Island Lake & 65 & $\mathbf{Y}$ & $\mathbf{N}$ & $\mathbf{Y}$ & $\mathbf{N}$ & Huish (1958b) \\
\hline Lake Beulah & - & $\mathbf{Y}$ & $\mathbf{N}$ & $\mathbf{Y}$ & $\mathbf{N}$ & Huish (1958a) \\
\hline $\begin{array}{l}\text { Percentage of studies meeting each } \\
\text { criterion }\end{array}$ & & 65 & 62 & 85 & 10 & \\
\hline
\end{tabular}

a Criteria: 1 = success of the removal is documented; $2=$ pre-removal data are presented: $3=$ the actual removal conditions are documented; $4=$ some estimate of variation is presented or data are statistically tested.

b This study was of the same removal reported in study $50 \mathrm{a}$, so satisfaction of criteria is not reflected in percentages at the bottom of the table (i.e., not duplicated).

turbidity might influence the vulnerability of shad to predators (e.g., Vinyard and O'Brien 1976; Savino and Stein 1982, 1989a, 1989b). In addition, monitoring sport-fish harvest is critical because increased angling mortality could obscure longterm population responses. Both abiotic and biotic variables must be monitored through time.

Manipulate only one variable. - Often, more than one manipulation occurred simultaneously within a single lake (e.g., introduction of brook silversides Labidesthes sicculus and shad simultaneously; size limits imposed during a shad manipulation). Clearly, such multiple management strategies confound interpretation of the results from any one manipulation. However, given that the goals of fisheries management (e.g., improved angling) typ- ically differ from the goal of fisheries research (understanding the mechanisms by which management manipulations effect changes in a fishery), manipulation of more than one variable may be necessary. Though we may accomplish management goals with multiple simultaneous manipulations, we learn little of underlying reasons for success or failure. Consequently, our ability to generalize about how particular manipulations influence the fish community has been compromised. Further, because the response of a fishery to multiple simultaneous management strategies will likely involve interaction among strategies, interpretation of the role of any one strategy will be impossible. When possible, we recommend manipulating only a single variable. 


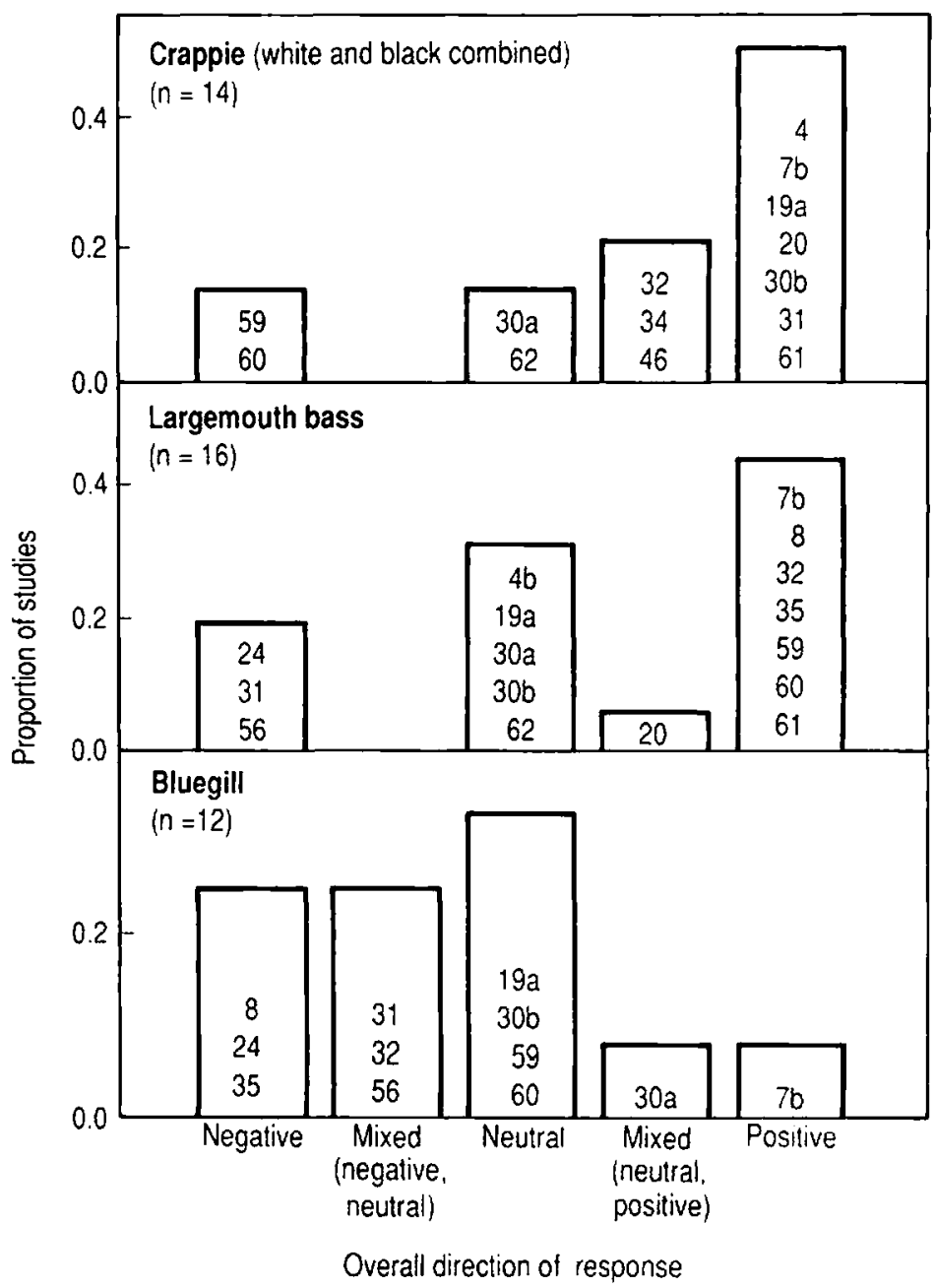

FIGURE 2,- Proportions of shad introductions that caused negative, neutral, positive, or mixed effects on white and black crappies, largemouth bass, and bluegill. To apportion studies into these categories, author-generated conclusions and interpretations were used. The total number of introductions ( $n$ ) is given in parentheses. Numbers within bars refer to the lakes and introductions in Figure 1 and Table 1.

Document manipulation success. - The influence of stocking or removing forage fishes depends on the extent of the manipulation itself. An increase from 0 to $5 \mathrm{prey} / \mathrm{m}^{2}$ is certainly a substantive change that should cause predators to respond. In contrast, how much must a shad population be reduced to reduce competition between shad and sport fishes? The size of foragefish populations must be estimated so managers can judge the extent of the response against the magnitude of the manipulation. In addition, to assure that predators directly benefit from an introduction, predator diets should be quantified before and after manipulation. Only in this fashion can we explicitly link changes in predator growth with the introduction. Finally, in studies of shad removal, the effects of the removal process on the target species, as well as its effects on the forage species, must be considered. If the target-species population is reduced, improved growth might occur due to reduced intraspecific, rather than interspecific, competition.

Additions versus removals. - Strong, sustained manipulations are required to detect system responses (Walters 1986; Carpenter 1989). Consequently, removals (partial removals in practice) are far less powerful than additions for elliciting a response (Carpenter 1989). Because shad are ex- 


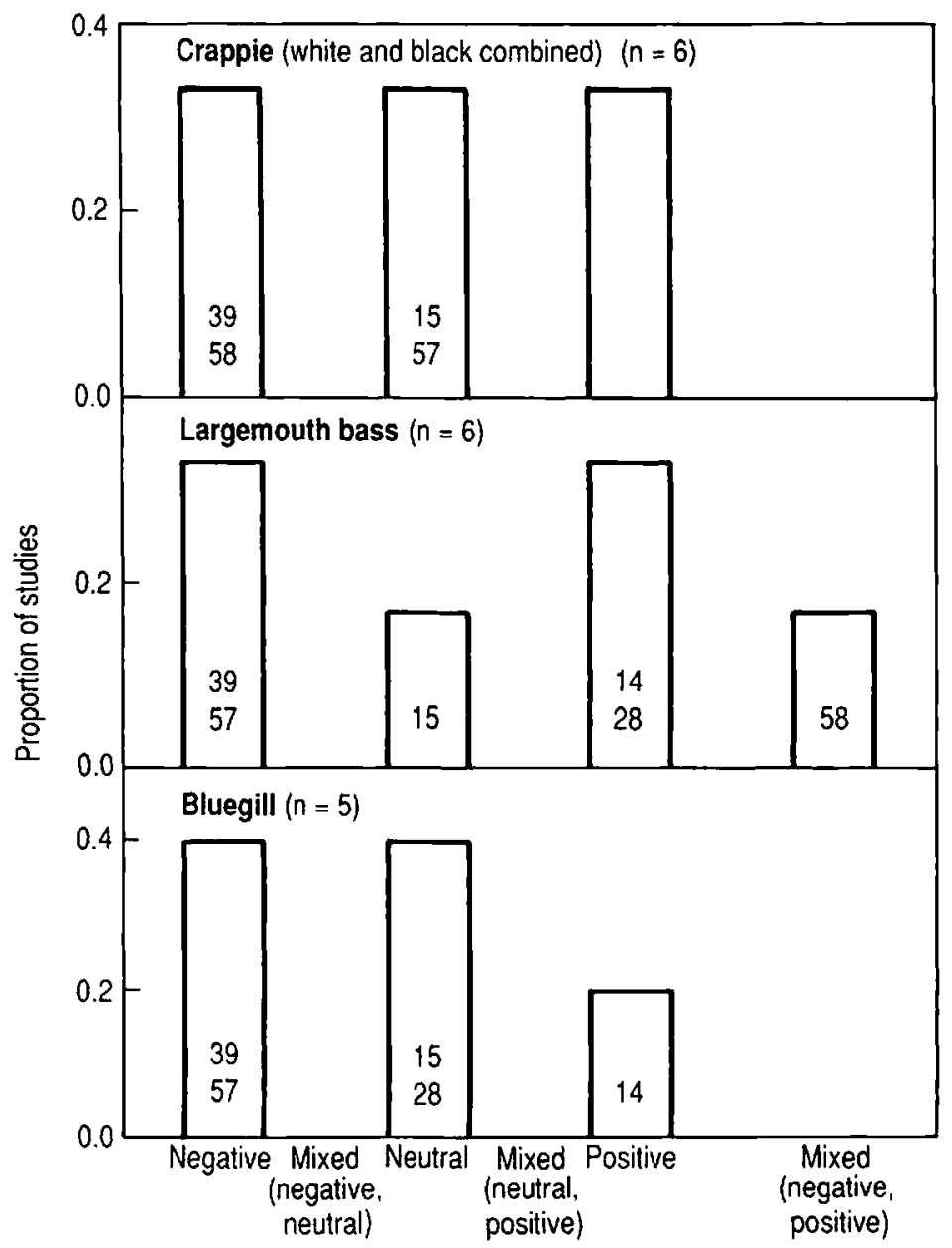

Overall direction of response

FIGURE 3.-Proportions of shad removals that caused negative, neutral, positive, or mixed effects on white and black crappies, largemouth bass, and bluegill. To apportion studies into these categories, author-generated conclusions and interpretations were used. The total number of removals $(n)$ is given in parentheses. Numbers within bars refer to the lakes and removals in Figure 1 and Table 2.

tremely fecund, the effects of a $50 \%$ reduction in the adult shad population may only be measurable over a single season. By the following year, a large forage-fish year-class could return the population to its original size. Though the introduction of shad may not result in an established population, quantifying this result is far easier than attempting to estimate the proportion removed. The difficulty of shad removal was substantiated by our review. Though results from shad additions were skewed (possibly influenced by investigator bias), no trends were apparent from removals. All target species experienced positive, neutral, and negative effects from shad removal. Consequently, if we are attempting to assess shad effects on ecosystem processes, effects are more likely to result from additions than from removals.

Include a reference system. - Studies of foragefish manipulations typically involve data collection across several years before and after the manipulation. To permit unambiguous interpretation of these manipulations, an unmanipulated reference lake (Likens 1985) should be monitored such that changes in the treatment lake can be explicitly attributed to the manipulation and not to year-toyear environmental variation. Though we recog- 
nize that the selection and use of a reference lake may be unrealistic in large ( $>200$-hectare) systems, the use of such lakes is critical to the interpretation of study results and may be reasonable for smaller systems; consequently, we discuss their use in this latter context.

The process by which an appropriate reference lake is selected is critical to interpretation of results. Lakes to be manipulated and those to be used as reference sites must be matched as closely as possible in terms of both biotic and abiotic variables (e.g., lake morphometry, shoreline development, abundance and type of vegetation, predator-prey complex, etc.). Toward this end, multivariate techniques, such as principal component analysis or discriminant analysis, could be used to identify appropriate reference lakes. Even when a reference lake is used, caution must be exercised when conclusions are drawn from comparisons of reference versus manipulated waters (see Walters et al. 1988).

All studies we reviewed included comparisons of response variables within the same system before and after the manipulation. Hurlbert (1984) termed this "temporal pseudoreplication" because one cannot determine if changes in predator growth rate (as an example) resulted from the manipulation or from some other unrelated cause, such as differences in weather. Hurlbert (1984) had a dismal view of this study design and argued that a "situation where a single control area and a single impact area are available" is intractable statistically. In contrast, Stewart-Oaten et al. (1986) argue that the effects of this type of manipulation can be evaluated statistically with data taken simultaneously and replicated in time before the manipulation, after the manipulation, and at both control (i.e., reference site) and impact sites (termed BACI design). We suggest that with growth data, back-calculated measures will suffice, but investigators must monitor a reference lake as well as the manipulated one. Manipulation effects are quantified by comparing the difference in response variables between reference and manipulated sites through time (Stewart-Oaten et al. 1986).

Often, year-to-year variation in the response variable within a system may be large and therefore may influence the ability of the $\mathrm{BACl}$ design to detect changes due to the manipulation. For example, the abundance of limnetic larval bluegills decreased by an order of magnitude after threadfin shad introduction into an Ohio lake, but the reduction was not due to the manipulation (DeVries
1989). Consequently, variation across years produced changes that could have incorrectly been attributed to the manipulation if only 2 years of data were used with a BACI design. In such cases, several years of data collection, before and after the manipulation, may be required to quantify annual variation.

To achieve adequate replication, multiple systems should be manipulated. However. given the extreme cost of monitoring whole systems in response to a manipulation, Carpenter (1989) and Carpenter et al. (1989) have carefully developed the case for unreplicated, paired-system experiments. Using randomized intervention analysis, Carpenter et al. (1989) argued that time-series data, such as those suggested by Stewart-Oaten et al. (1986), can be tested for changes after a manipulation.

Use statistics. - As discussed earlier, it is critical that statistics, or at least estimates of variation, be used in any analysis of a forage-fish manipulation. Without this crucial component, meaningful conclusions are not possible. Often, growth rates before and after a management manipulation are compared with back-calculated length-at-age data (see Summerfelt and Hall 1987). Because fish growth is a complex response to age and yearenvironment effects, estimates of variance apportioned to each of these contributing factors are required for managers to assess the value of a particular management manipulation. Consequently, we support an approach in which variance is apportioned into components attributed to age and the manipulation (Weisberg 1986; Weisberg and Frie 1987). This technique basically consists of a two-way analysis of variance, although single formulas for this explicit technique do not apply (Weisberg and Frie 1987). Rather, a more general technique including the use of general linear models (GLMs), such as the GLM procedure in SAS (SAS 1985), must be applied (Weisberg 1986; Weisberg and Frie 1987). With this technique, standard statistical tests can be applied with the explicit goal of determining whether growth changes have resulted from the manipulation itself or from random year-to-year effects.

Do large manipulations in a management context.-By definition, adding forage fishes to water bodies results in a whole-system manipulation. Because of the tremendous insight gained from this sort of technique, aquatic ecologists have embraced this approach (see individual chapters in Carpenter 1988a), although with several caveats. 
First, manipulations should be quite strong, substantially increasing or decreasing the abundance of the species of interest (Walters 1986; Kitchell et al. 1988; Carpenter et al. 1989). Weak manipulations often lead to misleading interpretations of the role of a species, and monitoring effort is wasted if the manipulation is so weak as to provide no effects. In such ill-fated experiments, pre- and postmanipulation data sets provide essentially no insight into system function, yet require much time and effort.

Our own experience in this regard may prove instructive. While planning a threadfin shad introduction into two reservoirs, we extensively debated the merits of high versus low stocking rates. Initially, low stocking rates (25-50 adults/hectare) appeared desirable, for they permitted economical hauling of adults. (Stocking rates of $250 \mathrm{fish} /$ hectare could not be maintained except on an experimental basis). In addition, low stocking rates would minimize competitive effects between shad and early life stages of sport fishes. In contrast, because hauling mortality and poststocking predation by largemouth bass could be substantial, high stocking rates might have made sense. Additionally, if the introduction failed, at least one full year of research effort would be lost, including all of the monitoring effort that year entailed. This conflict was resolved by stocking at a high rate with the proviso that future work be directed toward back-titrating to a lower, more economical stocking rate. We believe this example typifies the conservative nature of scientists and managers. Whereas much can be gained from a strong manipulation, initial tendencies are to design manipulations that lie within the historical experience of the investigators, and experiments are set up to "fine-tune" management policy before the limits of the system are known. We commend the advice of Walters (1986), who invoked an adaptive management approach in which management manipulations (as well as research ones) involve testing the limits of the system. We embrace the perspective that argues for participating in more daring experimental policy with uncertain outcomes (i.e., stronger manipulations in this context) than in policies that maintain the status quo (Walters 1986).

Finally, if possible, small-scale, mechanistic experiments should be done concurrently with the large-scale manipulation. In so doing, underlying mechanisms for observed phenomena can be tested, and generalizations for management application should emerge (Carpenter 1988b; Kitchell et al. 1988). Coupling these experiments with strong manipulations in a management context should yield information that is sufficient for evaluating new management strategies.

\section{An Alternative Approach}

Though forage-fish management has moved fishery biology from a simple consideration of single-species management to consideration of both predator and prey, additional system complexity confounds even this approach (Noble 1986). First, as is obvious, lake communities are composed of many trophic levels, all of which interact to some degree (Carpenter et al. 1985; McQueen et al. 1986; Crowder et al. 1988; Stein et al. 1988). For example, if threadfin shad are introduced into a largemouth bass-bluegill system, threadfin shad should increase prey resources for largemouth bass; however, because threadfin shad feed on zooplankton, as do larval and adult bluegills, bluegill and threadfin shad may compete. This competition may have a negative effect on bluegill (DeVries 1989; also suggested by Kirk and Davies 1987).

System complexity also increases because changes occur in diet and habitat use as fish grow (the ontogenetic niche; Werner and Gilliam 1984). For example, bluegill, crappies, and largemouth bass all feed on zooplankton as larvae (Werner 1967; Keast 1980, 1985a, 1985b; Beard 1982; Lemly and Dimmick 1982) and potentially compete with each other at this life stage. However, as these fish grow, diets change dramatically: bluegill diets shift to littoral invertebrates and zooplankton (Turner 1955; Seaburg and Moyle 1964; Keast 1978, 1985b; Beard 1982); crappie diets change from zooplankton to fish (Ellison 1984; O'Brien et al. 1984; Keast 1985a); and largemouth bass diets change even more quickly than those of crappies from zooplankton to fish (Applegate and Mullan 1967; Hamilton and Powles 1979; Keast 1980, 1985a, 1985b; Keast and Eadie 1985). Thus, shad and crappies can compete at one life stage and interact as predator and prey as the crappies grow.

Finally, we must consider how spatial heterogeneity affects community interactions in lakes and reservoirs. Because lakes and reservoirs have somewhat distinct littoral and limnetic habitats, any consideration of interactions among fishes must take into account the habitats occupied. For example, if threadfin shad feed in the limnetic zone and largemouth bass feed in the littoral zone, largemouth bass might not experience any positive effects due to the increased food abundance because of habitat segregation.

The importance of system complexity in affect- 
ing the overall outcome of forage manipulations is further illustrated by the results from introductions of opossum shrimp Mysis relicta (reviewed by Lasenby et al. 1986). In one of the earliest documented introductions, $M$. relicta was introduced into Kootenay Lake, British Columbia, in 1949 in an effort to improve growth rates of rainbow trout Oncorhynchus mykiss by providing an intermediate-size prey for young fish during the transition from a diet of zooplankton to one of fish (Sparrow et al. 1964). Although trout growth increased slightly, the fish did not feed extensively on $M$. relicta (Northcote 1973). In fact, eutrophication that followed the $M$. relicta introductions could have been responsible for this growth increase (Northcote 1972, 1973). However, growth of another species, kokanee Oncorhynchus nerka, increased substantially, encouraging further use of M. relicta as a forage supplement (Northcote 1970 , 1973). Mysis relicta exhibits diel migration and therefore influences the benthos during the day and limnetic zooplankton at night (Lasenby et al. 1986). Because trout rely on limnetic zooplankton for several years, any impact on this resource by $M$. relicta (as documented in numerous lakes; reviewed by Lasenby et al. 1986) could negatively affect trout growth. Thus, the very organism intended to improve adult trout growth could lead to a decline in juvenile trout growth through competition for zooplankton.

In a forage-fish manipulation, $\mathrm{Li}$ et al. (1976) monitored growth of crappies before and after introduction of inland silverside Menidia beryllina. They found that growth of piscivorous adult crappies increased significantly. However, crappie growth through the first 2 years was significantly reduced, likely due to competition with inland silversides for zooplankton. If reduced growth of smaller crappies leads to reduced survival. the overall effect of the introduction of inland silverside may actually be negative. In fact, the ultimate outcome from this manipulation could be some combination of these opposing effects on different sizes of the target species.

The results presented here indicate that several aspects of whole systems must be quantified if we are to assess how forage-fish manipulations affect a fish community. Based on our review of manipulations involving gizzard and threadfin shad, potential competition and predation, spatial refuges, indirect effects through common predators and prey, and the influence of ontogenetic shifts in habitat and diet of the target and introduced species are all critical to being able to predict the influence of a forage-fish manipulation on a target species.

\section{Conclusions}

We feel that a change to a community-oriented approach to fisheries management is necessary if we are to make the most rapid advances in our understanding of how to use forage fishes to improve a fishery. In future studies, better documentation (including statistical treatment of the data) is required if we are to gain an understanding of these manipulations. Only with studies that include well-designed experiments and appropriate analysis can management myths be prevented from perpetuating themselves.

We have the sense that most fishery biologists believe that the addition of forage fishes will increase the growth of predators and removal of forage fishes will increase competitor growth. This sense is based on our observation that there are many ongoing shad manipulations across the country. Our literature review suggests a lack of documentation indicating that fisheries improve after forage-fish manipulations. Consequently, until carefully designed field studies are completed, managers should not assume that shad manipulations will generate positive effects. Whether one is adding Mysis, silversides, or shad, unanticipated system-wide effects can dramatically undermine cven the best-intentioned efforts.

\section{Acknowledgments}

Thanks go to J. Boxrucker, P. L. Chesson, J. M. Dettmers, D. Gleckler, J. Jessel, X. Lazzaro, H. Li, W. M. Masters, M. E. Mather, G. G. Mittelbach, P. B. Moyle, B. Vondracek, and D. H. Wahl for many helpful comments on an carlier draft of this manuscript; T. Wickerham helped type and edit many drafts of the manuscript, and assisted in preparation of Figure 1. This work was supported by National Science Foundation grants BSR-8705518 to R.A.S. and BSR-8715730 to G. G. Mittelbach, and by funds from Federal Aid in Fish Restoration Project F-57-R to R.A.S., administered through the Ohio Division of Wildlife.

\section{References}

Aggus, L. R. 1974. Food of angler harvested largemouth, spotted, and smallmouth bass in Bull Shoals Reservoir. Proceedings of the Annual Conference Southeastern Association of Game and Fish Commissioners 27:501-505.

Anderson, W. M. 1983. Effect of stocking gizzard shad on the fishery in Little Dixie Lake, Missouri. Pages 58-77 in Bonneau and Radonski (1983).

Applegate, R. L., and J. W. Mullan. 1967. Food of young largemouth bass, Micropterus salmoides, in 
a new and old reservoir. Transactions of the American Fisheries Society 96:74-77.

Barger, L. E., and R. V. Kilambi. 1980. Feeding ecology of larval shad, Dorosoma, in Beaver Reservoir, Arkansas. U.S. Fish and Wildlife Service, Biological Services Program FWS/OBS-80/43:136-145.

Bartholomew, J. P. 1966. The effects of threadfin shad on white crappie growth in Isabella Reservoir, Kern County, California. California Department of Fish and Game, Inland Fisheries Administration, Report 66-6. Sacramento.

Beard. T. D. 1982. Population dynamics of young-ofthe-year bluegill. Wisconsin Department of Natural Resources Technical Bulletin 127.

Beers, G. D. 1965. Effects of a threadfin shad introduction upon black crappie and smallmouth buffalo populations in Roosevelt Lake. Master's thesis. University of Arizona, Tuscon.

Beers, G. D., and W. J. McConnell. 1966. Some effects of threadfin shad introduction on black crappie diet and condition. Journal of the Arizona Academy of Science 4:71-74.

Bonneau, D.. and G. Radonski, editors. 1983. Pros and cons of shad. Iowa Conservation Commission, Des Moines.

Brummett. K. 1983. Effects of gizzard shad introduction on the fishery of Lake Paho, Missouri. Pages 77-86 in Bonneau and Radonski (1983).

Carline, R. F., R. A. Stein, and L. M. Riley. 1986. Effects of size at stocking, season, largemouth bass predation. and forage abundance on survival of tiger muskellunge. American Fisheries Society Special Publication 15:151-167.

Carpenter, S. R. 1988a. Complex interactions in lake communities. Springer-Verlag, New York.

Carpenter, S. R. 1988b. Transmission of variance through lake food webs. Pages 119-135 in S. R. Carpenter, editor. Complex interactions in lake communities. Springer-Verlag, New York.

Carpenter. S. R. 1989. Replication and treatment strength in whole-lake experiments. Ecology 70:453463.

Carpenter, S. R., T. M. Frost, D. Heisey, and T. K. Kratz. 1989. Randomized intervention analysis and the interpretation of whole-ecosystem experiments. Ecology 70:1142-1152.

Carpenter, S. R., J. F. Kitchell, and J. R. Hodgson. 1985. Cascading trophic interactions and lake productivity. Bioscience 35:634-639.

Cramer, J. D., and G. R. Marzolf. 1970. Selective predation on zooplankton by gizzard shad. Transactions of the American Fisheries Society 99:320-332.

Crowder. L. B., and seven coauthors. 1988. Food web interactions in lakes. Pages 141-160 in S. R. Carpenter, editor. Complex interactions in lake communities. Springer-Verlag, New York.

Davies, W. D., B. W. Smith, and W. L. Shelton. 1979. Predator-prey relationships in management of small impoundments. Pages 449-458 in H. Clepper, editor. Predator-prey systems in fisheries management. Sport Fishing Institute, Washington, D.C.

DeVries. D. R. 1989. Complex interactions in aquatic communities: trophic-level interactions, ontogenetic niche shifts, and the role of an open-water planktivore. Doctoral dissertation. The Ohio State University, Columbus.

Dietz, E., and K. C. Jurgens. 1963. An evaluation of selective shad control at Medina Lake, Texas. Texas Parks and Wildlife Department, Inland Fisheries Report 5, Austin.

Domrose, R. J. 1963. Evaluation of threadfin shad introductions. Virginia Commission of Game and Inland Fisheries, Federal Aid in Fish Restoration, F-5-R-8, Final Report, Richmond.

Eder, S. 1983. Effects of gizzard shad introductions on the fisheries in three small lakes in northwest Missouri. Pages 100-107 in Bonneau and Radonski (1983).

Ellis, F. 1978. The effect of threadfin shad introductions in small impoundments. A literature review. Georgia Department of Natural Resources, Game and Fish Division, Project WC-5-1, Job Completion Report, Atlanta.

Ellis, F. 1981. The effect of winterkill of threadfin shad in Lake Jackson. Georgia Department of Natural Resources, Game and Fish Division, Project WC8, Final Report, Allanta.

Ellison, D. G. 1984. Trophic dynamics of a Nebraska black crappie and white crappie population. North American Journal of Fisheries Management 4:355364.

Fast, A. W., L. H. Bottroff, and R. L. Miller. 1982. Largemouth bass, Micropterus salmoides, and bluegill, Lepomis macrochirus, growth rates associated with artificial destratification and threadfin shad, Dorosoma petenense, introductions at El Capitan Reservoir, California. California Fish and Game 67: 4-20.

Fetterolf, C. M., Jr. 1957. Stocking as a management tool in Tennessee reservoirs. Proceedings of the Annual Conference Southeastern Association of Game and Fish Commissioners 10:275-285.

Hamilton, J. G., and P. M. Powles. 1979. Feeding habits and growth of young-of-the-year largemouth bass (Micropterus salmoides) near its northern limit, Nogies Creek, Ontario. Canadian Joumal of Zoology 57:1431-1437.

Heidinger, R. C. 1977. Potential of the threadfin shad as a forage fish in midwestern power cooling reservoirs. Transactions of the Illinois State Academy of Science 70:15-25.

Heidinger, R., and F. Imboden. 1974. Reproductive potential of young-of-the-year threadfin shad (Dorosoma petenense) in southern Illinois lakes. Transactions of the Illinois State Academy of Science 67: 397-401.

Heisey, P. G., D. Mathur, and N. C. Magnusson. 1980. Accelerated growth of smallmouth bass in a pumped storage system. Transactions of the American Fisherics Society 109:371-377.

Hepworth, D., and S. P. Gloss. 1976. Food habits and age-growth of walleye in Lake Powell, Utah-Arizona, with reference to introduction of threadfin shad. 
Utah Division of Wildlife Resources, Publication 76-15, Salt Lake City.

Hepworth, D., and T. D. Pettengill. 1980. Age and growth of largemouth bass and black crappie in Lake Powell, Utah-Arizona, with reference to threadfin shad introduction. Utah Division of Wildlife Resources, Publication 80-22, Salt Lake City.

Huish, M. T. 1958a. Studies of gizzard shad reduction at Lake Beulah, Florida. Proceedings of the Annual Conference Southeastern Association of Game and Fish Commissioners 11:66-70.

Huish, M. T. 1958b. Gizzard shad removal in Deer Island Lake, Florida. Proceedings of the Annual Conference Southeastern Association of Game and Fish Commissioners 11:312-318.

Hurlbert, S. H. 1984. Pseudoreplication and the design of ecological field experiments. Ecological Monographs 54:187-211.

Jackson. S. W., Jr. 1966. Summary of fishery management activities on Lakes Eucha and Spavinaw, Oklahoma. Proceedings of the Annual Conference Southeastern Association of Game and Fish Commissioners 19:315-342.

Jahn, L. 1983. Effects of gizzard shad and the fishery in a 250 acre Illinois lake. Pages $30-38$ in Bonneau and Radonski (1983).

Johnson, B. M., R. A. Stein, and R. F. Carline. 1988. Use of a quadrat rotenone technique and bioencrgetics modeling to evaluate prey availability to stocked piscivores. Transactions of the American Fisheries Society 117:127-141.

Keast, A. 1978. Feeding interrelations between agegroups of pumpkinseed (Lepomis gibbosus) and comparisons with bluegill (L. macrochirus). Journal of the Fisheries Research Board of Canada 35:1227.

Keast, A. 1980. Food and feeding relationships of young fish in the first weeks after the beginning of exogenous feeding in Lake Opinicon, Ontario. Environmental Biology of Fishes 5:305-314.

Keast, A. 1985a. The piscivore feeding guild of fishes in small freshwater ecosystems. Environmental Biology of Fishes 12:119-129.

Keast. A. 1985b. Development of dietary specializations in a summer community of juvenile fishes. Environmental Biology of Fishes 13:211-224.

Keast, A., and J. M. Eadie. 1985. Growth depensation in year-0 largemouth bass: the influence of diet. Transactions of the American Fisheries Society 114; 204-213.

Kimsey, J. B., R. H. Hagy, and G. W. McCammon. 1957. Progress report on the Mississippi threadfin shad in the Colorado River for 1956. California Department of Fish and Game, Inland Fisheries Administration Report 57-23, Sacramento.

Kirk, J. P. 1984. Competitive influences of gizzard shad introductions on balanced largemouth bass/ bluegill populations. Doctoral dissertation. Auburn University, Auburn, Alabama.

Kirk, J. P., and W. D. Davies. 1987. Competitive influences of gizzard shad on largemouth bass and bluegill in small impoundments. Proceedings of the
Annual Conference Southeastern Association of Fish and Wildlife Agencies 39:116-124.

Kirk, J. P., W. D. Davies, and K. Park. 1986. Response of some members of the fish community to gizzard shad removal from Chambers County Public Fishing Lake, Alabama. North American Journal of Fisheries Management 6:252-255.

Kitchell, J. F., and seven coauthors. 1988. Epistemology, experiments and pragmatism. Pages 263-280 in S. R. Carpenter, editor. Complex interactions in lake communities. Springer-Verlag, New York.

Kline, D. 1983. Gizzard shad-Lake Geode. Pages 3844 in Bonneau and Radonski (1983).

LaFaunce, D. A., J. B. Kimsey, and H. K. Chadwick. 1964. The fishery at Sutherland Reservoir, San Diego County, California. California Fish and Game 50:271-291.

Lasenby, D. C., T. G. Northcote, and M. Fürst. 1986. Theory, practice, and effects of Mysis relicta introductions to North American and Scandinavian lakes. Canadian Journal of Fisheries and Aquatic Sciences 43:1277-1284.

Lemly, A. D., and J. F. Dimmick. 1982. Growth of young-of-the-year and yearling centrarchids in relation to zooplankton in the littoral zone of lakes. Copeia 1982:305-321.

Lewis, W. M., and D. R. Helms. 1964. Vulnerability of forage organisms to largemouth bass. Transactions of the American Fisheries Society 93:315-318.

Li, H. W., P. B. Moyle, and R. L. Garrett. 1976. Effect of the introduction of the Mississippi silverside (Menidia audens) on the growth of black crappie (Pomoxis nigromaculatus) and white crappie ( $P$. annularis) in Clear Lake, California. Transactions of the American Fisheries Society 105:404-408.

Likens, G. E. 1985. An experimental approach for the study of ecosystems. Journal of Ecology 73:381396.

Mathias, J. A., and S. Li. 1982. Feeding habits of walleye larvae and juveniles: comparative laboratory and field studies. Transactions of the American Fisheries Society 1 11:722-735.

May, B. E., and C. Thompson. 1974. Impact of threadfin shad (Dorosoma petenense) introduction on food habits of four centrarchids in Lake Powell. Proceedings of the Annual Conference Western Association of State Game and Fish Commissioners 54: 317-343.

May, B. E., C. Thompson, and S. P. Gloss. 1975. Impact of threadfin shad (Dorosoma petenense) introduction on food habits of four centrarchids. Utah Division of Wildlife Resources, Publication 75-4. Salt Lake City.

McConnell, W. J., and J. H. Gerdes. 1964. Threadfin shad, Dorosoma petenense, as food of yearling centrarchids. California Fish and Game 50:170-175.

McGee, M. V., J. S. Griffith, and R. M. McLean. 1979. Prey selection by sauger in Watts Bar Reservoir, Tennessee, as affected by cold-induced mortality of threadfin shad. Proceedings of the Annual Conference Southeastern Association of Fish and Wildlife Agencies 31:404-411. 
McHugh, J. J. 1980. Northeast Virginia sport fishery studies. Virginia Commission of Game and Inland Fisheries, Federal Aid in Fish Restoration, Project F-37-R, Completion Report, Richmond.

McHugh, J. J. 1983. Evaluation of threadfin shad stocking in two Virginia lakes. Pages 124-133 in Bonneau and Radonski (1983).

McLean. R. B., J. S. Griffith, and M. V. McGee, 1985. Threadfin shad, Dorosoma petenense Günther, mortality: causes and ecological implications in a southcastern United States reservoir. Journal of Fish Biology 27:1-12.

McQueen, D. J., J. R. Post, and E. L. Mills. 1986. Trophic relationships in freshwater pelagic ecosystems. Canadian Journal of Fisheries and Aquatic Sciences 43:1571-1581.

Miller, E. E. 1971. The age and growth of centrarchid fishes in Millerton and Pine Flat reservoirs, California. California Department of Fish and Game, Inland Fisheries Administration, Report 71-4. Sacramento.

Morris, D. J., and B. J. Follis. 1979. Effects of striped bass predation upon shad in Lake E. V. Spence, Texas. Proceedings of the Annual Conference Southeastern Association of Fish and Wildlife Agcncies 32:697-702.

Mosher, T. D. 1983. Responses of white crappie and black crappie to threadfin shad introductions in a lake containing gizzard shad. Kansas Fish and Game, Federal Aid in Fish Restoration, Comprehensive Planning Option, Project FW-9-P-2, Pratt.

Mosher, T. D. 1984a. An evaluation of threadfin shad Dorosoma petenense introduction in Kansas. Kansas Fish and Game, Federal Aid in Fish Restoration, Comprehensive Planning Option, Project FW-9-P. 2, Pratt.

Mosher, T. D. 1984b. Responses of white crappie and black crappie to threadfin shad introductions in a lake containing gizzard shad. North American Journal of Fisheries Management 4:365-370.

Moss, J. L., and W. C. Reeves. 1983. Bluegill responses to threadin shad elimination in a 130 acre impoundment. Pages 150-168 in Bonneau and Radonski (1983).

Moyle, P. B. 1986. Fish introductions into North America: patterns and ecological impact. Pages 2743 in H. A. Mooney and J. A. Drake, editors. Ecology of biological invasions of North America and Hawaii. Springer-Verlag, New York.

Myhr, A. I., IIl. 1971. A study of the white bass, Morone chrysops (Rafinesque), in Dale Hollow Reservoir, Tennessee, Kentucky. Master's thesis. Tennessee Technological University, Cooksville.

Neuswanger, D. J. 1983. Effects of gizzard shad introductions on the fishery of Lake Paho, Missouri. Pages 87-99 in Bonneau and Radonski (1983).

Ney, J. J. 1981. Evolution of forage-fish management in lakes and reservoirs. Transactions of the American Fisheries Society 110:725-728.

Noble, R. L. 1981. Management of forage fishes in impoundments of the southern United States. Transactions of the American Fisheries Society 110 : 738-750.
Noble, R. L. 1986. Predator-prey interactions in reservoir communities. Pages 137-143 in G. E. Hall and M. J. Van Den Avyle, editors. Reservoir fisheries management: strategies for the 80's. American Fisheries Society, Southern Division Reservoir Committee, Bethesda, Maryland.

Northcote, T. G. 1970. Advances in management of fish in natural lakes of western North America. American Fisheries Society Special Publication 7: 129-139.

Northcote, T. G. 1972. Some effects of mysid introduction and nutrient enrichment on an oligotrophic lake and its salmonids. Internationale Vereinigung fuer Theoretische und Angewandte Limnologie Verhandlungen 18:1096-1106.

Northcote, T. G. 1973. Some impact of man on Kootenay Lake and its salmonids. Great Lakes Fisheries Commission Technical Report 25.

Norwat, D. H. 1978. Evaluation of threadfin shad introduction into Little Dixie Lake. Master's thesis. University of Missouri, Columbia.

O'Brien, W. J., B. Loveless, and D. Wright. 1984. Feeding ecology of young whitc crappic in a Kansas reservoir. North American Journal of Fisheries Management 4:341-349.

Prophet, C. W. 1982. Zooplankton changes in a Kansas lake 1963-1981. Journal of Freshwater Ecology 1: 569-575.

Prophet, C. W. 1985. Calanoid population structure in a Kansas lake after introduction of threadfin shad. Southwestern Naturalist 30:162-163.

Prophet, C. W. 1988. Changes in seasonal population structures of two species of Diaptomus (Calanoida, Copepoda) subsequent to introductions of threadfin and gizzard shad. Southwestern Naturalist 33:4153.

Putnam, T. 1983. Factors leading to renovation of two small Iowa public fishing lakes. Pages 134-141 in Bonneau and Radonski (1983).

Range, J. D. 1973. Growth of five species of game fishes before and after introduction of threadfin shad into Dale Hollow Reservoir. Proceedings of the Annual Conference Southeastern Association of Game and Fish Commissioners 26:510-518.

Rasmussen, J. L., and S. M. Michaelson. 1974. Attempts to prevent largemouth bass overharvest in three northwest Missouri lakes. Pages 69-83 in J. L. Funk, editor. Symposium on overharvest and management of largemouth bass in small impoundments. American Fisheries Society, North Central Division, Special Publication 3, Bethesda, Maryland.

Rose, E. T. 1957. Results of fish management at Blackhawk Lake. Iowa Conservation Commission Quarterly Reports 9(1):6-11.

Russell, K. 1983. The effect of gizzard shad on the bluegill fishery of Argyle Lake. Pages 175-177 in Bonneau and Radonski (1983).

Sandoz, O. 1956. Changes in the fish population of Lake Murray following the reduction of gizzard shad numbers. Proceedings of the Oklahoma Academy of Science 37:174-181. 
SAS. 1985. SAS users guide: statistics, version 5 edition. SAS Institute, Cary, North Carolina.

Savino, J. F., and R. A. Stein. 1982. Predator-prey interaction between largemouth bass and bluegills as influenced by simulated, submerged vegetation. Transactions of the American Fisheries Society 111 : 255-266.

Savino, J. F., and R. A. Stein. 1989a. Behavioral interactions between fish predators and their prey: effects of plant density. Animal Behaviour 37:311321.

Savino, J. F., and R. A. Stein. 1989b. Behavior of fish predators and their prey: habitat choice between open water and dense vegetation. Environmental Biology of Fishes 24:287-293.

Seaburg. K. G., and J. B. Moyle. 1964. Feeding habits, digestion rates, and growth of some Minnesota warmwater fishes. Transactions of the American Fisheries Society 93:269-285.

Smith, W. A., Jr. 1959. Shad management in reservoirs. Proceedings of the Annual Conference Southcastern Association of Game and Fish Commissioners 12:143-147.

Sparrow, R. A. H.. P. A. Larkin, and R. A. Rutherglen. 1964. Successful introduction of Mysis relicta Loven into Kootenay Lake. British Columbia. Journal of the Fisheries Research Board of Canada 21:13251327.

Stcin. R. A., and seven coauthors. 1988. Size-structured interactions in lake communities. Pages 161179 in S. R. Carpenter, editor. Complex interactions in lake communities. Springer-Verlag, New York.

Stewart-Oaten, A., W. W. Murdoch, and K. R. Parker. 1986. Environmental impact assessment: "pseudoreplication" in time? Ecology 67:929-940.

Summerfelt, R. C., and G. E. Hall. editors. 1987. Age and growth of fish. Iowa State University Press, Ames.

Trautman, M. B. 1981. The fishes of Ohio. Ohio State University Press, Columbus.

Turner, W. R. 1955. Food habits of the bluegill Lepomis macrochirus macrochirus (Rafinesque). in eighteen Kentucky farm ponds during April and May. Transactions of the Kentucky Academy of Science 16:98-101.

Van Den Avyle, M. J., and J. R. Wilson. 1980. Food habits and feeding selectivity of larval Dorosoma spp. in Center Hill Reservoir. U.S. Fish and Wildlife Service Biological Services Program FWS/OBS-80/ 43:146-156.

Vinyard, G. L., and W. J. O'Brien. 1976. Effects of light and turbidity on the reactive distance of bluegill (Lepomis macrochirus). Journal of the Fisheries Research Board of Canada 33:2845-2849.

VonGeldern, C. E., Jr. 1971. Abundance and distri- bution of fingerling largemouth bass, Micropterus salmoides, as determined by electrofishing, at Lake Nacimiento, California. California Fish and Game 57:228-245.

VonGeldern, C. E., Jr., and D. F. Mitchell. 1975. Largemouth bass and threadfin shad in California. Pages $436-449$ in $\mathrm{H}$. Clepper, editor. Black bass biology and management. Sport Fishing Institute, Washington, D.C.

Walters, C. J. 1986. Adaptive management of renewable resources. Macmillan, New York.

Walters. C. J., J. S. Collie, and T. Webb. 1988. Experimental designs for estimating transient responses to management disturbances. Canadian journal of Fisheries and Aquatic Sciences 45:530538.

Weisberg, S. 1986. A linear model approach to backcalculation of fish length. Journal of the American Statistical Association 81:922-929.

Weisberg. S., and R. V. Frie. 1987. Linear models for the growth of fish. Pages 127-143 in R. C. Summerfelt and G. E. Hall, editors. Age and growth of fish. Iowa State University Press. Ames.

Werner, E. E. 1986. Species interactions in freshwater fish communities. Pages 344-358 in J. Diamond and T. J. Case, editors. Community ecology. Harper and Row, New York.

Werner, E. E., and J. F. Gilliam. 1984. The ontogenetic niche and species interactions in size-structured populations. Annual Review of Ecology and Systematics 15:393-425.

Werner, R. G. 1967. Intralacustrine movements of bluegill fry in Crane Lake, Indiana. Transactions of the American Fisheries Society 96:416-420.

Werner, R. G. 1969. Ecology of limnetic bluegill (Lepomis macrochirus) fry in Crane Lake, Indiana. American Midland Naturalist 81:164-181.

Wyatt, H. N., and H. D. Zeller. 1965. Fish population dynamics following a selective shad kill. Proceedings of the Annual Conference Southeastern Association of Game and Fish Commissioners 16:411418.

Wydoski, R. S., and D. H. Bennett. 1981. Forage species in lakes and reservoirs of the western United States. Transactions of the American Fisheries Society 110 : 764-771.

Zeller, H. D., and H. N. Wyatt. 1967. Selective shad removal in southern reservoirs. Pages $405-414 \mathrm{in}$ Reservoir fishery resources symposium. American Fisheries Society, Southern Division Reservoir Committee, Bethesda, Maryland.

Ziebell, C. D.. J. C. Tash, and R. L. Barefield. 1986. Impact of threadfin shad on microcrustacean zooplankton in two Arizona lakes. Journal of Freshwater Ecology 3:399-406. 